\title{
11
}

\section{DENMARK, NORWAY AND SWEDEN}

\section{Share, make useful and critically discuss: Science communication}

Per Hetland, Dick Kasperowski and Kristian H. Nielsen

\section{Science communication in Scandinavia from the 15th century to the mid-20th century}

Scandinavia is the geographical region roughly comprising present-day Denmark, Norway and Sweden. The three Scandinavian countries have a shared cultural history, and the three national languages belong to the same dialect continuum and are mutually intelligible. Although the name Scandinavia can be traced back to the Roman natural philosopher Pliny the Elder, it only became popular during the 18th century when ideas about common identity and historical roots became prominent.

Danish, Norwegian and Swedish are all North Germanic languages. All three languages include direct translations of the German term wissenschaft, which traditionally is used to denote all spheres of knowledge from theology through the humanities to the social, natural, medical and practical sciences. Historically, the term populärwissenschaft and the related Scandinavian translations arose in the 19th century to denote communication of all sciences to non-academic audiences (Daum, 2002). Today, Danes, Norwegians and Swedes also talk about forskningsinformation, forskningsformidling and forskningskommunikation (literally, 'research information', 'research dissemination' and 'research communication'). Again, these terms imply all disciplines. 
King Christian I, who for a brief period in the 15th century restored the Kalmar Union with Denmark, Norway and Sweden under a single monarch, established the University of Copenhagen in 1479. During the Enlightenment period, scholars founded royal societies in Stockholm (1739), Copenhagen (1740) and Trondheim (1760) to advance and communicate scientific and practical knowledge. The late 18th and early 19th centuries also saw the establishment of royal societies dedicated to agriculture, forestry and mining.

Priests played an important role in this early phase of science communication, as they typically were the only persons in their local communities who had received higher education. A well-known example from the Scandinavian countries are the so-called 'potato priests' promoting potato cultivation among peasants (Brenna, 2011). The potato priests understood that potatoes, introduced into Scandinavia during the 18th century, were vital to the health and wellbeing of their congregations. They had to fight resistance to the new crop and superstitious beliefs about the potato causing disease and low yields in other crops. In the end, the public potato campaign was quite successful since potatoes constitute an important part of contemporary national diets; yet we have to remember that it also helped that people increasingly began to produce alcohol (aquavit and schnapps) from potatoes.

Science communication in Scandinavia really took off during the 19th century with the formation of societies and magazines dedicated to science popularisation, the opening of natural history museums and botanical gardens for the general public and, not least, the so-called rural awakening. The latter term indicates not only the spread of enlightened Christian thought, but also widespread interest in rural development and social stability. In the late 19th century and into the 20th, the newly formed national governments in the Scandinavian countries, partly inspired by the US agricultural extension model for diffusing the results of agricultural research to farmers, established agricultural test stations and other extension services. The rise of the Folk high school movement, providing adult education to the rural population, also meant that many more people were able to seek more or less science-based reasoning and information. 


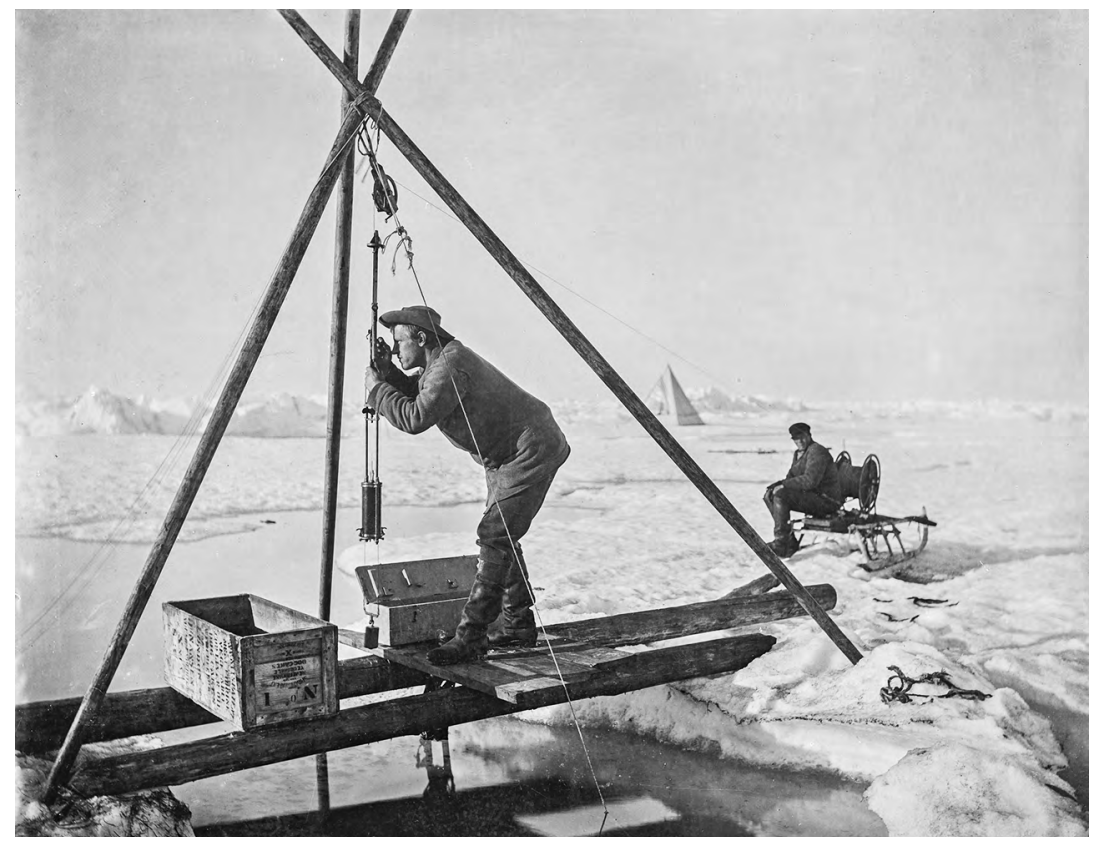

Figure 11.1: Scientific explorations are a source of national pride. Dr Nansen and the first Fram expedition (1893-96).

Source: The Fram Museum (used with permission).

During the 19th and 20th centuries, science communication played an important role in the formation of national identity. As mentioned, the very idea of a common cultural heritage in the three Scandinavian countries builds partly on literary and historical research. Scientific exploration, too, has had high visibility by way of the media and popular books. Explorers such as the Danish Knud Rasmussen, the Norwegian Fridtjof Nansen and the FinnishSwedish Adolf Erik Nordenskiöld all became national celebrities because, for many people, they combined scientific discovery with national pride, understanding and unity. The explorer-as-national-hero tradition continues up until today, although the distinction between scientific and popular exploration seems to have become sharper.

Industrialisation during the 19th century proceeded at an uneven pace, with Sweden leading the way followed by Denmark and Norway. Primary industries such as farming, forestry, fishing and mining, however, remained the mainstay of the Scandinavian economies up until the 1930s. It was in the 1930s and 1940s that all three Scandinavian countries established the prevailing, but largely implicit, social contract between science and society, relying on widespread ideas of social corporatism, consensus and citizenship. The state agreed with various corporate groups such as agricultural, labour, 
trade and scientific associations that science and technology were key factors in driving economic growth and welfare. This political consensus lent broad support for collaborations between public and private research, but also for higher education, lifelong learning and public communication of science and technology. At the core of society was the informed citizen, responsible for their own self-improvement and enlightenment.

In what follows we will treat the emergence of contemporary science communication in each of the three Scandinavian countries from roughly the end of World War II onwards. Although Denmark, Norway and Sweden fared very differently during the war, the post-war period for all countries to a high degree revolved around the development of the welfare state. The welfare state model combined internationalism and liberal capitalism with a large public sector organised into many subsectors such as education, health, military, research, etc. Science policy therefore emerged as 'a proper concern of government', as Vannevar Bush put it in his 1945 report to the US president, Science: The Endless Frontier (Bush, 1945). In Scandinavia, the national governments established many public sector research organisations to produce and communicate knowledge relevant to sectorial governance. More or less at the same time, the Nordic countries, comprising the three Scandinavian countries as well as Finland and Iceland, established the Nordic Council in 1952 , driven by the desire to make the Nordic region one that people would want to live and work in.

\section{The emergence of modern science communication in Denmark}

Compared to other European countries, Denmark remained relatively untouched by the damages from World War II. For most of the war, Denmark continued to cooperate politically and economically with the German occupation forces and, due to the cooperative atmosphere and the availability of dairy products, the German occupation soldiers soon nicknamed Denmark die Sahnefront (literally, the Cream Front) (Poulsen, 1991). Following the war, Denmark immediately sought to re-establish its foreign relations and made the defence of the realm a top priority. Denmark joined the United Nations in June 1945 and the North Atlantic Treaty Organization (NATO) in April 1949. In addition, Denmark's share of the European Recovery Program (the Marshall Plan) was relatively higher than its two neighbouring Scandinavian countries, Norway and Sweden. By the late 1950 s, the industrial sector overtook the agricultural sector in relative size in terms of national employment, and from the 1960s onwards public sector investments led to the development of a strong welfare state. 
In the immediate post-war period, scientists and journalists were optimistic about science communication. Communicating science, they believed, was important not only for general education but also for the public appreciation and understanding of science. Already during the war, Børge Michelsen, one of the first Danish science journalists, had begun campaigning for improved working conditions for younger scientists. Warning against what he called the 'proletarianisation of science', Michelsen together with a few scientists petitioned the government for the establishment of a committee for the advancement of science in Denmark. Due to the collapse of the protectorate government in August 1943 when the German occupation forces took full control of Denmark, the government did not establish the committee until after the war (Nielsen, 2008a).

Børge Michelsen established the Association of Danish Science Journalists in 1949. The association was short-lived, having little impact on the field of science journalism in Denmark. In 1951, one of the other founding members, Niels Blædel, played an important role in the campaign for the advancement of science in Denmark that Michelsen had helped set in motion. By this time, Michelsen had left Denmark to accept the position of head of the Division for Science and its Popularisation at UNESCO (Nielsen, 2018). The campaign culminated when thousands of scientists and students marched the streets of Copenhagen in favour of increased government support for scientific research and higher education. Blædel took part in the organisation of the demonstration, covering it extensively in his newspaper, Politiken. Because of the mounting pressure to advance science, the government established the first public research foundation in 1952. The foundation soon became known as the State's Carlsberg Foundation in reference to the fact that before 1952 most support for basic research had come from private foundations such as the Carlsberg Foundation (Knudsen, 2006).

When these events took place in Copenhagen, a large science-mediagovernment partnership was well underway, namely the Galathea Deep Sea Expedition 1950-52. Like the campaign to advance science, preparations for the expedition had begun during the war where explorers were planning to launch a Danish expedition foundation after the war. Their purpose was dual. They wanted not only to support three Danish scientific expeditions-one to Greenland, one to Central Asia and one circumnavigation of the globe, i.e. the Galathea Expedition-but also to communicate to audiences at home and abroad that the collaboration with Nazi Germany during the war had been a complete mistake since Denmark really stood for peace, international collaboration and scientific research. The Galathea Expedition had its own media section, consisting of the head of the section journalist-explorer Hakon 
Mielche, one other journalist and three photographers. The media section reported on the expedition through telegrams, magazine articles, books, films and radio features (Nielsen, 2008b).

Throughout the 1950s and 1960s, the Danish Broadcasting Corporation (DR) increased its coverage of science and technology. There were regular TV and radio shows about science, most aimed at adult education. Still, the most popular science broadcasts seem to have been radio lectures, a continuation of a tradition established in the interwar years. In 1957, DR launched its Sunday University, a weekly radio show on Sunday from 11 am $-12 \mathrm{pm}$, where scientists and lecturers from all disciplines gave lectures on historical, literary, philosophical, scientific, technological and other issues. The show became hugely popular, continuing into the 1970 s. DR also produced a book series to accompany the lectures. One of the reasons for the show's popularity was probably its so-called 'radiophonic' adaptation, where the DR journalists would carefully select proper subject matters and edit the presenter's lecture notes so that listeners with no academic education would also see the lectures as interesting and be able to understand them (Nielsen and Nielsen, 2006).

Unprecedented economic growth, but also cultural upheaval and sociopolitical change, characterised 1960s and early 1970s Denmark. The anti-nuclear and environmental movements along with Marxist-inspired social critique led to public debate about societal inequalities as well as the health and environmental risks produced by capitalism, science and technology. When the Association of Danish Science Journalists again formed in 1976, its members included 'red' science journalists who saw critical science journalism, quite often with a Marxist bent, as a form of counter-expertise. They strongly believed that scientists and science journalists would have a crucial role to play in transforming the industrial, capitalist society to a socialist one (Waneck, 2005).

The renewable energy movement became strong in the course of the 1970s, enabling new formats of science communication. Wind energy in particular was an important renewable energy source for a country like Denmark with its long traditions in wind turbine development and scarce energy resources in terms of sun, rivers, forests and fossil fuels, but with a lot of wind. To promote wind energy as a viable alternative to coal, oil and nuclear power, engineers, researchers, renewable energy activists, green politicians, wind turbine producers and owners, science journalists and many others created informal, yet strongly interconnected, grassroots communication networks supporting a high degree of learning-by-interaction and public participation in sociotechnical issues relating to wind energy. Regular informal meetings, magazines, booklets, television programs, political activism and professional engineering communication were all means to promote knowledge sharing and gain public visibility (Nielsen and Heymann, 2012). 


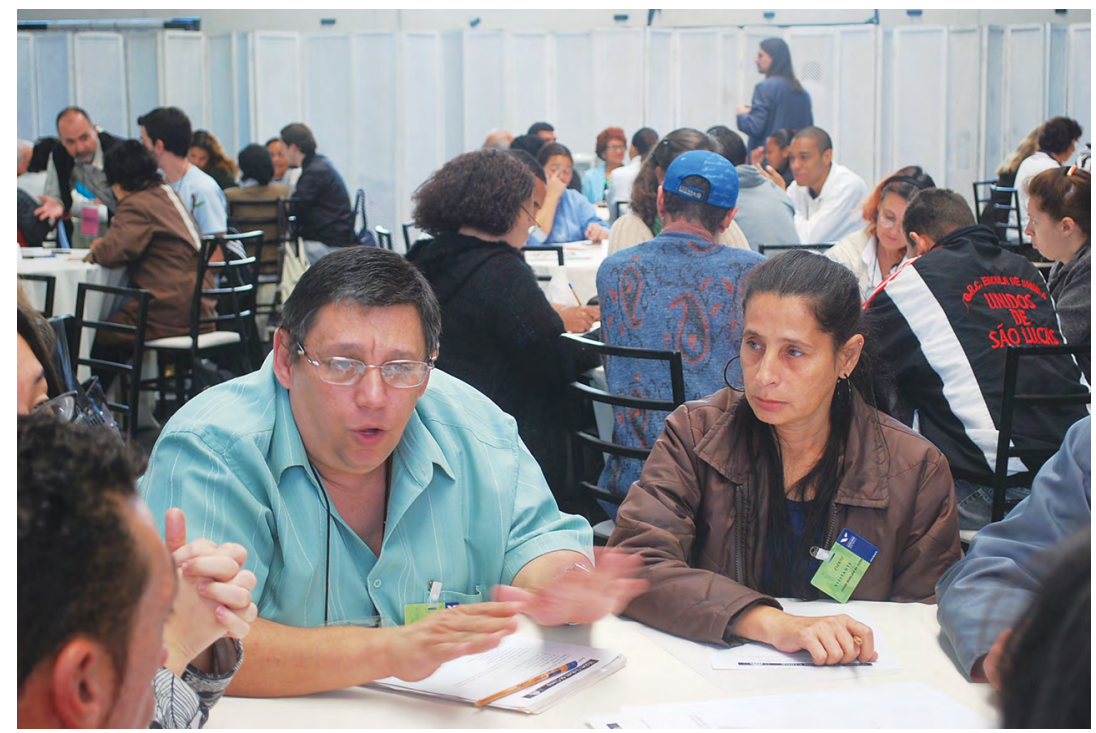

Figure 11.2: Leading up to COP15 in Copenhagen in 2009, the Danish Board of Technology initiated the first World Wide Views (WWViews) consultation on global warming, which was the first-ever global citizen consultation with roughly 4,000 citizens in 38 countries. The picture shows citizens in São Paulo, Brazil, deliberating some of the core issues at stake.

Source: The Danish Board of Technology (used with permission).

The Danish Parliament established the Danish Board of Technology (DBT) in 1986 to communicate knowledge about new technology and its societal consequences. The parliament and the board understood technology assessment, the board's remit, as involving not only expert assessments, but also public deliberation and public participation. The board developed and employed many deliberative and participatory methods such as scenario workshops, citizen juries and consensus conferences. The first consensus conference in Denmark predates the establishment of the DBT, taking place in 1983 on the theme of breast cancer. In contrast to the model developed in the United States by the National Institutes of Health, where the expert panel would prepare the final consensus document, Danish consensus conferences typically result in a consensus statement authored by the citizen panel. The DBT have been instrumental in making the Danish-style consensus conferences popular around the world. Scholars have argued that the work of the DBT demonstrates the strength of integrative political processes with respect to scientific and technological issues by institutionalising a close link between political and participatory aspects of democracy, thus enforcing the Danish culture of consensus (Andersen and Jæger, 1999; Horst and Irwin, 2010). 
Despite-or maybe because of-Denmark's strong tradition of public participation in science, the Danish Government introduced the third mission for Danish universities rather later than other European countries (Zomer and Benneworth, 2011). The 2003 Act on Universities introduced the idea that the Danish universities (all universities are public) are obligated to 'collaborate with the surrounding society and contribute to the development of international collaboration'. In May 2003, the Minister of Science, Helge Sander, established a think tank on the public understanding and appreciation of science that included mostly people working with journalism and communication. The think tank propounded the term 'research communication' as a way to provide citizens with enough knowledge and competencies to be able to enter into 'a democratic dialogue about research, its results and processes, its benefits and opportunities, its consequences, dilemmas and risks' (Tænketanken for forståelse for forskning, 2004). The think tank recommended allocating 2 per cent of all research grants to research communication and funds for research in research communication, but did not specify if this meant 2 per cent of the total pool of funds, or 2 per cent of each individual grant. Although many Danish scientists were positive towards the 2 per cent recommendation, the ministry never enacted it (Nielsen et al., 2007). The ministry did, however, announce two funding schemes for research in research communication and established the national Festival of Research, another one of the think tank's recommendations.

The third mission of the Danish universities introduced in 2003 really has two elements (Aagaard and Mejlgaard, 2012). First, the universities should contribute to growth, welfare and development in society. Second, as important institutions of knowledge and culture, they should exchange knowledge and competencies with actors in society, disseminate knowledge about scientific results and methods to the public and encourage their employees to take part in public debate. Studies indicate that most scientists and engineers have limited engagement in any kind of third mission activities, but those that do tend to engage in public sector service, industrial collaboration or executive involvement (Mejlgaard and Ryan, 2017). Researchers from the humanities, however, are overwhelmingly engaged in disseminating knowledge to the public through books, newspapers, magazines, blogs and social media (Johansson et al., 2018). 


\section{The emergence of modern science communication in Norway}

At the beginning of World War II, the Norwegian academic system remained relatively untouched. However, in 1942, a large number of schoolteachers were sent to labour camps in northern Norway, and the University of Oslo was closed in November 1943. At the beginning of 1944, 'most of the academic leaders, both students and staff, were imprisoned, hiding, or in exile' (Fure, 2018, p. 113). Many of those held in concentration camps in Germany, and still living there at the end of the war, were saved by a rescue operation organised by the Swedish Red Cross and Danish Government only weeks before the collapse of the Third Reich. During the war one notable form of science communication was a large number of articles, pamphlets and books telling people how to secure their own subsistence. Following the war, Norway, similarly to Denmark, joined the United Nations in June 1945 and NATO in April 1949. As with Denmark, Norway received important assistance through the US's Marshall Plan, and a number of scientists and engineers travelled to the US to learn. Quite likely this aid led to the Norwegian academic system being strongly inspired by the Anglo-American one, and it has had long-lasting effects.

However, to explain the position of Norway it is necessary to take one step back. Due to the country serving as the junior partner in two unions, first with Denmark (1380-1814) and then with Sweden (1814-1905), academic institutions arrived late in Norway. What is now known as the University of Oslo was established in 1811. The University of Oslo played an important role in meeting the intellectual needs of the emerging independent nation of Norway. In fact, it has been said that the University of Oslo has gone through three distinct periods of development, with each period having a marked influence on Norwegian society (Myhre, 2018):

1. A national civil servant university (until approximately 1880) that educated the professionals needed to serve the state.

2. The growth of a research university with a definite national flavour from about 1880. Norwegian scientists mostly 'excelled-internationally speaking-in disciplines connected to practical and national interests in fisheries, shipping and polar exploration: meteorology, geology, oceanography, marine biology and studies of the northern lights' (Myhre, 2018, p. 23).

3. An internationalised mass university from approximately 1960 onward. 
These three periods of development also reflect changing understandings of science communication. Science communication delivered as an element of formal education was the dominant task during the first period of the university's life, while popular science communication became part of the process of national identity formation and modernisation from the 1880s until the 1960s. Finally, during the third period, science communication in Norway evolved in parallel with that seen in the other Nordic countries.

During the 19th and 20th centuries, polar exploration was important for developing a national identity. This tradition was revived after World War II. The best-known Norwegian explorers of recent times are arguably Helge Ingstad (1899-2001), who is internationally recognised for mapping Viking settlements in Canada (Ingstad, 2009, 2010); and Thor Heyerdahl (19142002), who is internationally renowned for his experimental archaeology and numerous expeditions (Kvam, 2005, 2008, 2013). Both explorers produced a great number of popular books, presentations and documentary films, and Heyerdahl in particular had a large international audience, with his books being translated into more than 70 languages. The documentary film chronicling the Kon-Tiki expedition won a number of international awards. Both Ingstad and Heyerdahl also used the new mass media of the time, namely radio and TV, to spread news of their achievements, while the KonTiki Museum was established in 1949. Polar studies are still important, and Norway has several research facilities in the Arctic and Antarctica. Climate change has spurred science communication with both stakeholders and different publics.

Although several authors have attempted to analyse science and technology communication in Norway from a broader perspective (Andersen and Hornmoen, 2011; Bentley and Kyvik, 2011; Kyvik, 2005; Løvhaug, 2011), there have been only a very few analyses of the Norwegian science and technology communication policy framing those communication activities (Hetland, 2014). Approximately 50 per cent of all faculty members published at least one popular science article during a three-year period (1989-91 and 1998-2000), although just 6 per cent of faculty members published half of all popular science articles (Kyvik, 2005).

The third mission was first mentioned in the law governing the University of Bergen in 1948, then in the revised law governing the University of Oslo in 1955. In 1995, the law governing all public higher education institutions adopted the third mission, as did the revised law governing both public and private higher education institutions in 2005. Finally, in 2013, the expanded and strengthened Act Relating to Universities and University Colleges declared that higher education institutions have three key missions: 
education, scientific research, and science and technology communication. Consequently, science and technology communication is sometimes referred to as 'the third mission'. This states that the universities should: 1) contribute to the public communication of science and technology; 2) contribute to innovation; and 3) ensure the participation of higher education staff in public debate. One important condition in relation to engaging in the third mission is academic freedom (Underdal et al., 2006), which from 2007 was explicitly included in the Act Relating to Universities and University Colleges.

In this context, it is also important to note that the Norges forskningsråd (NFR, the Research Council of Norway) is the major player funding research and promoting science communication on a larger scale, as private money plays only a minor role. The overall objective of the NFR's national science communication strategy is: 'Through a general dissemination of research, the aim is to encompass that part of the general public who are not traditional users of research simultaneous to including research in the public debate' (Norges forskningsråd, 1997, p. 7). Three main groups of people are defined as being especially important in this regard:

1. Children and young people, who will form the basis for the recruitment of future researchers.

2. Teachers, who serve as disseminators of research results to their pupils.

3. Journalists, who disseminate research and, due to their position, can influence the science policy debate.

Several different activities promoted science communication in Norway. The Norwegian Contest for Young Scientists was launched as a private initiative in 1968, although it quickly grew in terms of both its ambition and its scope. The Nysgjerrigper Science Knowledge Project for children attending primary school was established in 1990, and the Norwegian Science Week was inaugurated in 1995, the same year in which the Science Channel was established as a joint project conducted between the largest universities and university colleges, resulting in weekly transmissions by the Norwegian Broadcasting Corporation. This activity took place alongside the launch of a number of other projects directed toward children and young people, including TV series such as Newton. Forskning.no was established in 2002 as an online newspaper devoted to Norwegian and international science, included several possibilities for feedback and debate. ScienceNordic was launched in 2011 with science news from the Nordic countries in English.

The Science Centres Program was established in 2003 as an important project, not least in terms of stimulating the interest of young people in the STEM fields (science, technology, engineering and mathematics). By 2018, Norway 
had nine regional science centres, as well as five additional specialised science centres. It was considered important to strengthen museum-based activities aimed at schools. Both the museums and the science centres adopted the use of social media platforms in order to increase the possibilities for inquirybased learning. Finally, the Researcher Grand Prix was established in 2010 and proved an exciting opportunity for doctoral candidates to learn valuable skills in communicating their research, and at the same time participate in a national competition.

The concept of environmental citizenship has grown in importance since 1900, although it had its first significant breakthrough during the 1970s, both as a popular movement and as a growing concern within Norwegian universities (Anker, 2011; Berntsen, 2011). Hydropower accounts for almost all of Norway's electricity production. Yet the fight against the extensive building of hydroelectric power plants broadly lasted throughout the 1970s and culminated in debates about the Alta Hydroelectric Power Scheme in the early 1980s. This conflict caused a number of environmental organisations to engage in activities intended to strengthen their collaboration with the indigenous people of the north, the Sami. Science communication was used extensively to argue for a more sustainable environmental policy. Such ecological arguments relied on the natural sciences, as well as on the social sciences and humanities. A key intellectual and inspirational figure within the environmental movement was Professor Arne Næss from the University of Oslo. He coined the term 'deep ecology', and he had a long-lasting influence across various disciplines both within and outside academia. A more traditional approach to environmental issues was presented within the established political regime by former Prime Minister Gro Harlem Brundtland, chair of the Brundtland Commission, which led to the publication of the Brundtland Report on sustainable development in 1987. Within just two decades, environmental concerns had become a matter of general concern within the international policy arena.

The Norwegian authorities recognised the need for new forums to encourage active public debate concerning technology and in 1999, inspired by the Danes, they established the Norwegian Board of Technology. This was tasked with determining the possibilities and consequences associated with new technologies, for both society and individual citizens. Its findings were to be made known to the parliament, as well as to other authorities and to the public. The board was allowed to determine both the specific areas for discussion and its working methods. However, importance was to be attached to the methods by which laypeople could become engaged in its activities. Today, the Norwegian Board of Technology employs several working methods, such as hosting laypeople's conferences, workshops, citizens' panels and hearings. 
In other words, the Norwegian authorities wish to engage the general public in a more comprehensive debate concerning technology. A little before this, the NFR launched a policy for user-oriented science communication in 1996. The policy underlines that user-oriented science communication requires two-way communication between the researcher and the user. The aim is to empower the user to act.

Two distinct trends are currently apparent within the field of Norwegian science communication, namely a stronger emphasis on open science (OS), and the growing professionalisation of science communication, including more public relations within academia. Within the long-term Norwegian plan for research and higher education (Kunnskapsdepartementet, 2018), OS is assigned a high priority. In most documents concerning OS, transparency and knowledge-sharing are emphasised. Scientific publications based on research and development projects funded wholly or partially by the Research Council are to be made openly accessible to all interested parties to the greatest extent possible. At the same time, participation in the actual performance of science is to be opened up.

It is often taken for granted that OS and citizen science (CS) are two sides of the same coin; however, this issue is not as straightforward as might initially be expected (Kennedy, 2016). Several initiatives work toward achieving greater openness, and in Norway, most CS projects, for example, in relation to biodiversity mapping, encourage openness and inclusiveness. For instance, the Ministry of Climate and Environment, through the Norwegian Biodiversity Information Centre, launched a new service known as Artsobservasjoner [Species Observations] in 2008. It is a digital reporting system that is open to everybody. Between 2008 and 2018, about 20 million observations have been recorded, mostly by amateur naturalists. These observations are crucial in many respects, with one application being the species map service used by planners and the like. Consequently, CS represents one emerging method of participatory science communication (Hetland, 2011). In 2013, Farbrot published a guidebook concerning practical science communication that remains much in use (Farbrot, 2013). The book illustrates how science communication is increasingly converging with PR. However, more empirical studies of both phenomena in the Norwegian context are required as academic institutions increasingly establish their own communication units, on all levels, to promote science communication. 


\section{The emergence of modern science communication in Sweden}

Sweden remained neutral during World War II, and neutrality required allocating substantial state funds to national defence. In general, due to a national focus on self-sufficiency requiring that Sweden itself produce and provide as much as possible of what the country needed, research received generous funding. Particularly, money went to forestry, mining and food production, which helped boost the Swedish economy in the post-war period. During the war, initiatives such as the establishment of the so-called Kursverksamheten KV (literally, course activity), which later became Folkuniversitetet (the People's University, one of many adult education activities known as studieforbund, or study unions) served to strengthen general education and serve as intellectual resources to resist Nazism and fascism (SOU, 1946:68, p. 28).

In the 1960s, initiatives in research policy started to move beyond a rhetoric on bildung and democracy. The longstanding ideal of bildung in Sweden was inspired by the German tradition of self-cultivation, where philosophy, personal experiences, formal and informal education are envisioned as resulting in personal and cultural maturation. This is often described as a harmonisation of the individual's mind and heart and a unification of selfhood and identity with the national culture or society. However, this ideal, as an individual project, was now questioned in calls for concrete practices and incentives for the public communication of science. Industry had since long been the prioritised recipient for research results and the natural partner for cooperation (in Swedish, samverkan), with the universities. However, now a more intense discussion took place over why the communication of science was to be directed at the public.

The general argument was that Swedish society had now reached a state of 'scientification' realising the need for every citizen to understand and communicate scientific knowledge. Without this information, citizens would not be able to take part in societal decision-making, and, ultimately, this would lead to a democratic deficit (Universitetskanslersämbetet, 1972). Science communication providing citizens with access to research information, therefore, was more than entertainment, education and formation; it had become a civil right and democratic virtue.

The wider context for this discussion was science policy initiatives during the 1950s-1960s in creating the Sectorial Principle in Swedish research. This stated that state authorities with responsibility for sectors such as 
environment, defence, education, etc. also had the responsibility to produce the knowledge necessary to fulfil their politically defined mission. Usually these tasks were commissioned from researchers at the universities, but who were now criticised for producing knowledge below scientific standards. The criticism of the Sectorial Principle was two-fold: that the science it generated was substandard, and that, importantly, it created a dislocation of power in Swedish society, from elected members of parliament to experts in the administration of state authorities.

During the latter part of the 1970s and into the 1980s and 1990s, the belief that the Swedish state could control and steer societal development with an increasingly instrumentally motivated research policy lost ground to arguments based on research quality and excellence. The allocation of resources for scientific research should no longer be left to civil servants in government, but rather should be performed by the universities where peer review and other mechanisms for scientific quality could be guaranteed. Research was to be brought back to the universities, so to speak, yet at the same time it was also important to ensure the public were involved in discussions about science.

In the latter part of the 1970s, long-established relations between industry and university research largely defined the official Swedish policy on science communication and the formal relationships between universities and society. The organisation of science communication outside government and industry, mainly defined by concepts such as bildung and democracy, was in a different situation. Although sometimes resources were shared with the industrial networks, other actors, particularly the organisations involved in adult education, were responsible for communicating science to the public. In spite of this, the Higher Education Law of 1977 stated that university researchers now had a 'third mission' to fulfil, and it was their responsibility to inform and collaborate with society, and from 2009 to make their knowledge useful.

The Law was largely the result of discussions following several public inquiries and a product of university administrators and politicians (Universitetskanslersämbetet, 1972; Centrala organisationskommittén för högskolereformen, 1975). Traditionally, the Law has been taken as evidence for the opening up of the Swedish university. It encouraged researchers to communicate their work and results to the public, on the basis that this work was funded by taxpayers' money. Thus, research was brought back to the universities from the sectorial sphere, assigning the task of communicating high-quality scientific results to the researcher responsible for creating those results. 
The Law was constituted on 10 February 1977 . The sixth paragraph stated:

That work at the universities shall also include to disseminate knowledge on research and development. Knowledge shall also be disseminated on what experiences and knowledge have been gained and how this knowledge shall be applied (Regeringens proposition om utbildning och forskning inom högskolan m m., 1977).

The Law prescribes a third task for the Swedish universities, in addition to the well-established tasks of education and research. It is not evident if the third mission is associated with any new economic resources allocated to the universities. In the referral process preceding the Law, no institutions made any enquires on the possibilities of increased resources from the state for the universities in their work with the third mission. It appears as if the universities did not perceive of the third mission as something more, new or requiring extra funding. In the formulation of the law there is no information about the intended recipients of science communication. It is not self-evident that it is the general public as such or individual or groups of citizens that are targeted for the efforts in the dissemination of research.

Forskningsrådsnämnden (FRN, Swedish Council for Planning and Co-ordination of Research) was established in February 1977 as a state authority to oversee the third mission. Sweden is unique in having a state authority from 1977 to 2000, to initiate, investigate and oversee public communication of science. Swedish researchers have to a large extent been considered as insufficient or inadequate in their assigned task to communicate science to the public. This is largely because little value or importance has been assigned to the third task by the Swedish research community, in spite of many attempts since the late 1970s (both in terms of legislation and education) to encourage public communication of science.

However, it would be a mistake to believe that Swedish researchers do not engage in such activities. Later studies have shown that researchers communicate their research extensively, legislation or not, and create strategies to accommodate public communication of science in already established and recognised value systems of merit.

The standard tale is that Swedish scientists do not engage in public communication of science. However, this is a result built upon evaluations and surveys, not looking into the practices of the research community. In an upcoming book on the history of the third mission in Sweden, applications for professorships at Swedish universities have been systematically analysed. The data show that researchers are doing much of what can be subsumed under the third mission, but they categorise these efforts as 'education' or 
'research' using traditional categories of merit. Publishing in a popular science magazine can be called 'research overview', giving public lectures called 'education', etc. (Kasperowski, Bragesjö and Kullenberg, in progress).

FRN's assumption was that science communication and the third mission would not happen by itself: researchers must be encouraged, trained or even coerced into communicating with the public. The 'societal side' of the university has to be evoked by laws and, most often in the history of FRN, supplemented with different stimulus packages such as workshops in writing popular science, courses for $\mathrm{PhD}$ students, journalist exchange programs, etc., all of which encourage and support researchers in their efforts to fulfil the third mission obligations. Several FRN reports have lamented the fact that researchers are not rewarded for third mission activities as they gain relatively little merit for these activities compared to research and teaching, and minimal economic resources have been made available for public communication of science (Ramström, 1986, p. 74).

Even proposals to establish courses in science communication for researchers have been met with scepticism from university boards, because they thought that other types of training and qualifications, particularly for PhD students, were more important. This led to several recommendations by FRN, among them a proposal to the government of issuing a complementary higher education regulation in 1985. The Swedish Government accepted the FRN recommendations, stating that individual researchers should be rewarded and promoted for their 'research information' activities together with scientifically meritorious outputs, pedagogical work and other skills (Högskoleförordning, 1985).

The government assigned the universities the task to coordinate their communication and information activities. However, no funds were allocated for this, and the local universities had to prioritise existing funding. Together with the Swedish Office for Higher Education, FRN was assigned the task of overseeing that the new regulation was actually applied in employment procedures at the universities. However, an analyst contracted by the FRN concluded that Swedish researchers were well prepared to deal with the third mission and therefore did not need training or coercion by law. To be a researcher is also to be able to communicate your work to students and the public (Ramström, 1986, p. 46). The problem cannot be fought focusing on the individual researcher or PhD student; it is of a structural kind. When advice is issued to FRN in the report it is stated that 'research information should be directed to a general public not to a narrowly defined group of professionals for their use in their everyday work' (Ramström, 1986, p. 25). 
FRN was critical of the report since communicating research information to professionals is also part of activities it promotes, and here the longstanding conflict of science communication in Sweden becomes visible. Public communication of science is resting upon an image of diffusion from researchers at the higher seats of learning, coupled with a very strong rhetoric on the needs of the modern knowledge-based representative democracy, including citizens with a high degree of trust in science as an institution. However, this rhetoric has seldom been realised in any larger coordinated projects or programs. Communication of science to professionals in industry, policy and business has, since the 1920s, been an integral part of the cooperation between universities and 'the surrounding society', enjoying infrastructural and economic resources. This tradition does not produce a strong rhetoric of democracy, but is often clad in innovation and global competition, and has at times affected the trust for science and research negatively in Sweden.

During the late 1990s, FRN as a state authority was questioned by prominent natural scientists regarding the distribution of large grants for the procurement of advanced technologies for research in the natural and medical sciences. In the late 1990s, FRN was shut down following a dispute over the handling of large research grants, and its responsibilities (including science communication) were handed over to the Swedish Research Council. The shutdown of FRN was thus not motivated by any arguments concerning the public communication of science. Now, the responsibility for developing new initiatives in science communication was to be carried out by the research council and the universities themselves. Whereas the limited distribution of funds to public communication of science by FRN had been directed to projects initiated by individual researchers and on the training of researchers in science communication, the Swedish Government now wants the research councils to take responsibility for increasing researchers' options for reaching out to the public (Forskning för kunskap och framsteg, 1993).

What is the image of the Swedish researcher as a public communicator of science in the light of ideals and practices employed by FRN? The general answer is that Swedish researchers cannot be steered, trained or encouraged to fulfil the third mission - they simply fail to adhere to the different initiatives taken by FRN. In particular, this is the fact concerning communication of science to the general public carried out with the ideals of bildung and democracy.

None of the strategies for solving the problem of the low value placed on public communication of science by FRN seem to result in any significant change among Swedish researchers, with some exceptions. The first successful example dates from the late 1970 s and is characterised by the creation of a new public 
for science communication (Dewey, 1991; Marres, 2005). In 1980, after several years of public debate Sweden held a public referendum on nuclear power. FRN early on produced a popular science booklet series called Källa. The referendum on nuclear power in Sweden gave FRN the opportunity to produce several issues on nuclear power, many of them debates between researchers from different disciplines and moderated by a 'neutral' researcher. The articles on nuclear power in Källa were considered an important contribution to the public debate. Over 50 volumes of Källa were published during 1980-2003, presenting new and socially relevant research, debated and moderated by the researchers themselves. Usually research identified by the FRN as important 'from a societal perspective' was debated. Environment and energy, health and medicine, the relation between technology, nature and culture, digitalisation and, during the later 1990s, biotechnology were recurrent themes. This initiative has almost paradoxical qualities: given the right circumstances, Swedish researchers are not reluctant to fulfil the third mission and they also seem to have the communicative skills necessary.

A further example concerns calls and applications to the position of professor at Swedish universities. Historical data show that despite the low merit value of third mission activities, they are actually being practised. Document analysis of applications to the position of professor $(n=126)$ on all faculties from 1976-1982 and 1996-2002 at the University of Gothenburg shows that applicants do communicate their science to the public; however, they manage the low merit value by constructing their efforts as 'education' or 'research'. The low value merit value of third mission activities means that they do not attract rewards, do not help secure positions at universities, and even that you can be accused of producing 'popular science' instead of original research. Public communication of science is thus constructed or subsumed under already recognised categories of merit. Calls for applications, however, very seldom put public communication as a requirement for the position as professor, third mission or not (Kasperowski, Bragesjö and Kullenberg, in progress).

The third example is a demand put on researchers by funders from the late 1990 s onwards in Sweden in relation to research applications. Sweden is a country where it is necessary to obtain external funding for research, since positions as lecturers are usually primarily funded only to fulfill educational tasks. The incentives to apply for external funding are therefore high and competitive, since research and publications are the hard currency for career movement. From the late 1990s onwards, all Swedish major funders of research have requested researchers to draft popularised versions of their research proposals. This is true for the Swedish Research Council, established 
in 2001 and supporting research of the highest quality within all scientific fields, and previously for the specialised, disciplinary research councils as well as FRN. ${ }^{1}$

Swedish researchers do publicly communicate science almost independently of the Higher Education Law. The construction of the Swedish researcher as not fulfilling a role as a communicator of science to the public is, at least in view of our limited data, a narrative decoupled from the practices of Swedish researchers. Today, discussions on public communication of science and research in Sweden are to a large extent defined by open science and the possibilities of opening science further 'upstream' in the research process itself, and the communication efforts needed for such a change. Universities are increasingly taking advantage of social media and digital resources as a large cadre of communicators are now developing a new ecology of science communication in Sweden.

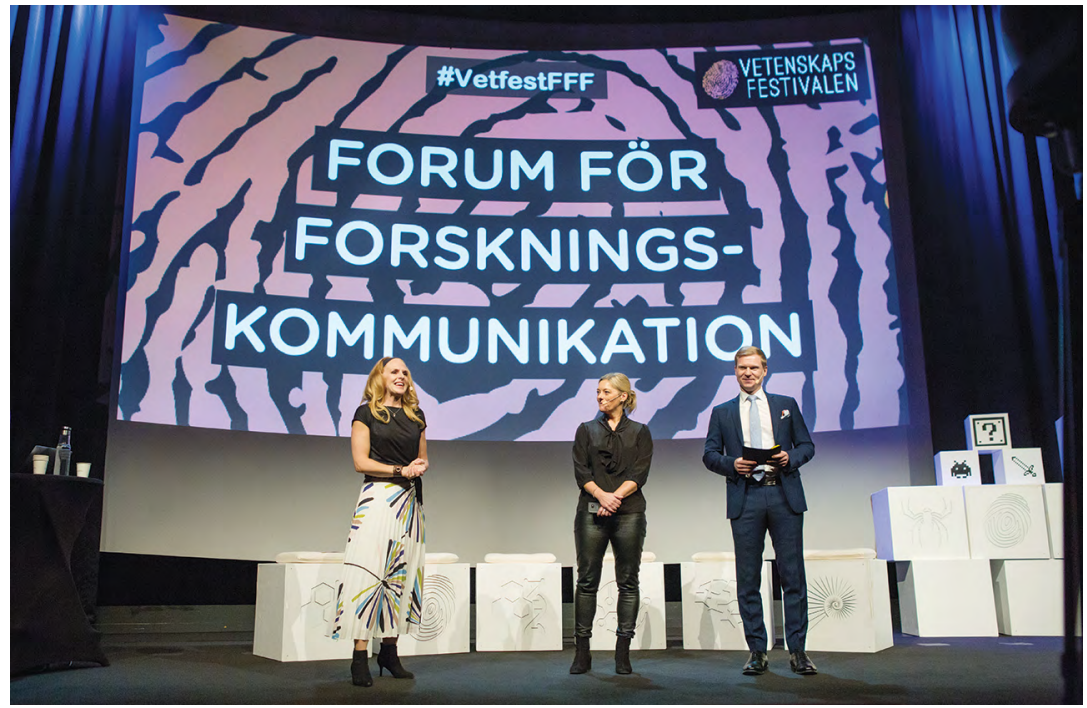

Figure 11.3: Forum for Forskningskommunikation [Forum for Research Communication] is an annual event held in relation to Vetenskapfestivalen Göteborg [International Science Festival Gothenborg]. The forum brings together science communicators, scientists and others to discuss pertinent topics in relation to science communication. The topic of the 2019 event was 'Impact: Good, bad or dangerous?'.

Source: International Science Festival Gothenborg (used with permission).

1 Interview of Anna-Maria Fleetwood, Senior Adviser, External Relations, Swedish Research Council, by Dick Kasperowski, 4 October 2018. 


\section{Concluding remarks}

Denmark, Norway and Sweden all have a rich history of science communication. Popularisation efforts by the scientific community have co-existed and co-developed with efforts to make science communication useful for the purposes of democracy, education, farming, environmental protection, industrial development, public health, social welfare and more. One of the challenges faced in all three countries is how to match the demands of the academic community, particularly attuned to specialist, technical communication, with the demands of society (including most academics), hoping to share, make useful and critically discuss the fruits of research. The enactment of the third mission for all public universities serves as a modern example of such a match, but also shows the difficulties involved. There are many similarities across the three countries covered in this chapter, such as an ongoing emphasis on the role of science communication in enforcing citizenship, public deliberation and social responsibility, but also many differences. The making of modern science communication in Scandinavia also testifies to the fact that Denmark, Norway and Sweden are-and always have been-firmly embedded in international developments.

As open economies, the three Scandinavian countries have a long tradition of international collaboration. Denmark joined the present EU in 1973, Sweden in 1995 and Norway joined the European Economic Area in 1994. As such, they are all three collaborating partners of Horizon 2020, and national science policy is strongly influenced by EU policy. An important policy objective is to ensure that the results of publicly funded research are made open and available to the different publics. Furthermore, responsible research and innovation is high on the agenda. One crucial question for each of the three countries is how they manage to build bridges between international ambitions and national publics facilitating science communication that build identity and citizenship.

\section{References}

Aagaard, K. and Mejlgaard, N. (eds) (2012). Danskforskningspolitik efter årtusindskiftet. Aarhus, Aarhus University Press.

Andersen, E. K. and Hornmoen, H. (2011). Mediating Science in Norway: Practices and Transformations in Major Newspapers. Media Transformations, 5, 88-104.

Andersen, I.-E. and Jæger, B. (1999). Scenario workshops and consensus conferences: towards more democratic decision-making. Science and Public Policy, 26, 331-40. doi.org/10.3152/147154399781782301. 
Anker, P. (2011). Den store økologiske vekkelsen som har hjemsøkt vårt land. In P. Anker, M. Gulbrandsen, E. Larsen, J. W. Løvhaug and B. S. Tranøy (eds), Universitetet i Oslo 1811-2011: Samtidshistoriske perspektiver (pp. 103-71). Oslo, Unipub.

Bentley, P. and Kyvik, S. (2011). Academic Staff and Public Communication: A Survey of Popular Science Publishing Across 13 Countries. Public Understanding of Science, 20(1), 48-63. doi.org/10.1177/0963662510384461.

Berntsen, B. (2011). Grønne linjer: Natur- og miljøvernets historie i Norge. Oslo: Unipub.

Brenna, B. (2011). Clergymen Abiding in the Fields: The Making of the Naturalist Observer in Eighteenth-Century Norwegian Natural History. Science in Context, 24, 143-66. doi.org/10.1017/S0269889711000044.

Bush, V. (1945). Science: The Endless Frontier. Washington DC: United States Government Printing Office.

Centrala organisationskommittén för högskolereformen (H 75). (1975). Högskolelag och andra författningar för högskolan. Stockholm, LiberLäromedel/Utbildningsförl. för Utbildningsdep.

Daum, A. W. (2002). Wissenschaftspopularisierung im 19. Jahrhundert: Bürgerliche Kultur, Naturwissenschaftliche Bildung und die Deutsche Öffentlichkeit, 1848-1914. München, Oldenbourg. doi.org/10.1515/9783486832501.

Dewey, J. (1991). The public and its problems. Athens, OH: Swallow Press.

Farbrot, A. (2013). Forskningskommunikasjon: Praktisk håndbok for forskere og kommunikasjonsrägivere. Oslo: Cappelen Damm Akademisk.

Forskning för kunskap och framsteg. (1993). Regeringen Proposition 1992/93:170.

Fure, J. S. (2018). A university under siege. In K. Helsvig and J. E. Myhre (eds), Making a Modern University: The University of Oslo 1811-2018 (pp. 11-39). Oslo: Scandinavian Academic Press.

Hetland, P. (2011). Science 2.0: Bridging Science and the Public. Nordic Journal of Digital Literacy, 6, 326-39.

Hetland, P. (2014). Models in Science Communication Policy: Formatting Public Engagement and Expertise. Nordic Journal of Science and Technology Studies, 2(2), 5-17. doi.org/10.5324/njsts.v2i2.2144.

Högskoleförordning. (1985). Svensk författningssamling, SFS nr 1977: 26, kapital $19, \$ 30$.

Horst, M. and Irwin, A. (2010). Nations at Ease with Radical Knowledge: On Consensus, Consensusing and False Consensusness. Social Studies of Science, 40, 105-26. doi.org/10.1177/0306312709341500.

Ingstad, B. (2009). Eventyret: en biografi om Helge Ingstad. Oslo: Gyldendal. 
Ingstad, B. (2010). Oppdagelsen: en biografi om Anne Stine og Helge Ingstad. Oslo: Gyldendal.

Johansson, L. G., Pedersen, D. B. and Stjernfelt, F. (2018). Humanistiske universitetsforskeres vidensformidling og videnssamarbejde. Copenhagen: Humanomics, Aalborg University.

Kasperowski, D., Bragesjö, F. and Kullenberg, C (in progress). Den tredje uppgiften: Lagarna, folket och forskarna [The third mission: The laws, the people and the researchers].

Kennedy, E. B. (2016). When Citizen Science Meets Science Policy. In D. Cacalier and E. B. Kennedy (eds), The Rightful Place of Science: Citizen Science (pp. 21-50). Tempe, AZ: Consortium for Science, Policy \& Outcomes.

Knudsen, H. (2006). Politik, penge og forskningsvilkår. In H. Nielsen and K. H. Nielsen (eds), Viden uden granser, 1920-70. Dansk Naturvidenskabs Historie, bind 4 (pp. 21-50). Aarhus: Aarhus University Press.

Kunnskapsdepartementet. (2018). Langtidsplan for forskning og høyere utdanning 2019-2028. Oslo: Kunnskapsdepartementet.

Kvam, R. (2005). Thor Heyerdahl: Mannen og havet. Oslo: Gyldendal.

Kvam, R. (2008). Thor Heyerdahl: Mannen og verden. Oslo: Gyldendal.

Kvam, R. (2013). Thor Heyerdahl: Mannen og mytene. Oslo: Gyldendal.

Kyvik, S. (2005). Popular Science Publishing and Contributions to Public Discourse Among University Faculty. Science Communication, 26(3), 288-311. doi.org/ 10.1177/1075547004273022.

Løvhaug, J. W. (2011). Overlæreren i rampelyset: Universitetet i mediesamfunnet 1970-2011. In P. Anker, M. Gulbrandsen, E. Larsen, J. W. Løvhaug and B. S. Tranøy (eds), Universitetet i Oslo 1811-2011: Samtidshistoriske perspektiver (pp. 367-459). Oslo: Unipub.

Marres, N. S. (2005). No issue, no public: democratic deficits after the displacement of politics (PhD thesis). Amsterdam, Ipskamp Printpartners. Retrieved from pure.uva. nl/ws/files/3890776/38026_thesis_nm_final.pdf.

Mejlgaard, N. and Ryan, T. (2017). Patterns of third mission engagement among scientists and engineers. Research Evaluation, 26, 326-36. doi.org/10.1093/ reseval/rvx032.

Myhre, J. E. (2018). The University of Oslo through 200 years: From national civil servant school to mass university. In K. Helsvig and J. E. Myhre (eds), Making a Modern University: The University of Oslo 1811-2018 (pp. 11-39). Oslo: Scandinavian Academic Press. 
Nielsen, K. H. (2008a). Enacting the social relations of science: historical (anti-) boundary-work of Danish science journalist Borge Michelsen. Public Understanding of Science, 17, 171-88. doi.org/10.1177/0963662506067661.

Nielsen, K. H. (2008b). In quest of publicity: the science-media partnership of the Galathea Deep Sea Expedition from 1950 to 1952. Public Understanding of Science, 18, 464-80. doi.org/10.1177/0963662507083529.

Nielsen, K. H. (2018). 1947-1952: UNESCO's Division for Science \& Its Popularisation. Public Understanding of Science, E-Pub Ahead of Print, 12 November. doi.org/10.1177/0963662518787572.

Nielsen, K. H. and Heymann, M. (2012). Winds of change: communication and wind power technology development in Denmark and Germany from 1973 to ca. 1985. Engineering Studies, 4, 11-31. doi.org/10.1080/19378629.2011.649921.

Nielsen, K. H., Kjaer, C. R. and Dahlgaard, J. (2007). Scientists and science communication: a Danish survey. Journal of Science Communication, 6(1). doi.org/ $10.22323 / 2.06010201$.

Nielsen, K. H. and Nielsen, H. (2006). Formidling af naturvidenskab i presse, radio og tv. In H. Nielsen and K. H. Nielsen (eds), Viden uden grenser, 1920-70. Dansk Naturvidenskabs Historie, bind 4 (pp. 405-22). Aarhus: Aarhus University Press.

Norges forskningsråd. (1997). Nasjonal strategi for allmennrettet forskningsformidling. Oslo: Norges forskningsråd.

Poulsen, H. (1991). Die Deutsche Besatzungspolitik. In R. Bohn et al. (eds), Neutralität und totalitäre Aggression: Nordeuropa und die Grossmächte im Zweiten Weltkrieg (pp. 369-79). Stuttgart: Franz Steiner Verlag.

Ramström, D. (1986). Att dela med sig av kunskapens glädje: en utvärdering av FRNs stöd till högskolans forskningsinformation. Rapport 86:8. Stockholm: Forskningsrådsnämnden.

Regeringens proposition om utbildning och forskning inom högskolan m.m. (1977). 1976/1977:59.

Statens offentliga utredningar (SOU). (1946:68). Betänkande och förslag angående det fria och frivilliga folkbildningsarbetet. D.1, Allmänt folkbildningsarbete: 1944 års folkbildningsutredning. Stockholm.

Tænketanken for forståelse for forskning. (2004). Forsk og fortal! Copenhagen: Ministry of Science.

Underdal, A., Ullenius, C., Storsul, T., Olsen, J. P., Kjenndalen, K., Hagesæter, G. Giertsen, J., Bernt, J. F. and Rigmor, A. (2006). Akademisk frihet: Individuelle rettigheter og institusjonelle styringsbehov. Oslo: Kunnskapsdepartementet/Norges offentlige utredninger. 
Universitetskanslersämbetet. (1972). Förslag till försöksverksamhet med forskningsinformation. Stockholm: SAMSUS.

Waneck, M. (2005). Rød naturvidenskab (Master's thesis). Aalborg, Aalborg University. Retrieved from projekter.aau.dk/projekter/files/6145654/Rød\%20Naturviden skab.pdf.

Zomer, A. and Benneworth, P. (2011). The Rise of the University's Third Mission. In J. Enders, H. F. de Boer and D. F. Westerheijden (eds), Reform of Higher Education in Europe (pp. 81-101). Rotterdam: Sense Publishers. doi.org/10.1007/978-946091-555-0_6.

\section{Timeline}

\begin{tabular}{|c|c|c|c|}
\hline Event & Denmark & Norway & Sweden \\
\hline $\begin{array}{l}\text { First interactive science } \\
\text { centre established }\end{array}$ & $\begin{array}{l}1991 \\
\text { Experimentarium }\end{array}$ & $\begin{array}{l}1914 \\
\text { Norwegian } \\
\text { Museum of } \\
\text { Science and } \\
\text { Technology }\end{array}$ & $\begin{array}{l}1985 \\
\text { Teknorama }\end{array}$ \\
\hline $\begin{array}{l}\text { First national (or large } \\
\text { regional) science festival }\end{array}$ & 2005 & 1975 & 1997 \\
\hline $\begin{array}{l}\text { An association of science } \\
\text { writers or journalists } \\
\text { or communicators } \\
\text { established }\end{array}$ & $1949 / 1976$ & 1952 & 1972 \\
\hline $\begin{array}{l}\text { First university courses } \\
\text { to train science } \\
\text { communicators }\end{array}$ & 2006 & 2013 & 2003 \\
\hline $\begin{array}{l}\text { First master's students } \\
\text { in science communication } \\
\text { graduate }\end{array}$ & & 1992 & 2004 \\
\hline $\begin{array}{l}\text { First } \mathrm{PhD} \text { students in } \\
\text { science communication } \\
\text { graduate }\end{array}$ & 2003 & 1990 & 2002 \\
\hline $\begin{array}{l}\text { First national conference in } \\
\text { science communication }\end{array}$ & 2005 & 2007 & 2012 \\
\hline $\begin{array}{l}\text { National government } \\
\text { program to support } \\
\text { science communication } \\
\text { established }\end{array}$ & 2006 & 1996 & $1977-2000$ \\
\hline $\begin{array}{l}\text { First significant initiative } \\
\text { or report on science } \\
\text { communication }\end{array}$ & 2004 & 1993 & 1977 \\
\hline $\begin{array}{l}\text { National Science Week } \\
\text { founded }\end{array}$ & 2016 & 1995 & 1983 \\
\hline
\end{tabular}




\begin{tabular}{|l|l|l|l|}
\hline Event & Denmark & Norway & Sweden \\
\hline $\begin{array}{l}\text { A journal completely or } \\
\text { substantially devoted to } \\
\text { science communication } \\
\text { established }\end{array}$ & 1854 & 1877 & $\begin{array}{l}1911-(1916) \\
1906-\end{array}$ \\
\hline $\begin{array}{l}\text { First significant radio } \\
\text { programs on science }\end{array}$ & 1933 & 1952 & $1930 / 1937$ \\
\hline $\begin{array}{l}\text { First significant TV } \\
\text { programs on science }\end{array}$ & 1956 & 1959 & Late 1950s/1971 \\
\hline $\begin{array}{l}\text { First awards for scientists } \\
\text { or journalists or others for } \\
\text { science communication }\end{array}$ & $1996 / 2004$ & 1995 & 1972 \\
\hline $\begin{array}{l}\text { Date hosted a PCST } \\
\text { conference }\end{array}$ & 2008 & $1995 / 2005 / 2013$ & $1977 / 1997 / 2009$ \\
\hline $\begin{array}{l}\text { Other significant events: } \\
\text { Law on third mission for } \\
\text { the universities }\end{array}$ & 2003 & & 2008 \\
\hline
\end{tabular}

\section{Contributors}

Dr Per Hetland is professor at the University of Oslo, Department of Education. He holds a Dr Philos. in science communication from the University of Oslo and a PhD in innovation studies from Roskilde University.

Dick Kasperowski is associate professor of Theory of Science at the University of Gothenburg. Informed by current perspectives in science and technology studies, his main interests include citizen science, governance of science, participatory practices in science and the humanities and open collaborative projects in scientific work.

Dr Kristian Nielsen is associate professor and head of the Centre for Science Studies, Aarhus University. He is currently working on the emergence of public understanding of science. 
This text is taken from Communicating Science: A Global Perspective, edited by Toss Gascoigne, Bernard Schiele, Joan Leach, Michelle Riedlinger, Bruce V. Lewenstein, Luisa Massarani and Peter Broks, published 2020 by ANU Press, The Australian National University, Canberra, Australia.

doi.org/10.22459/CS.2020.11 